
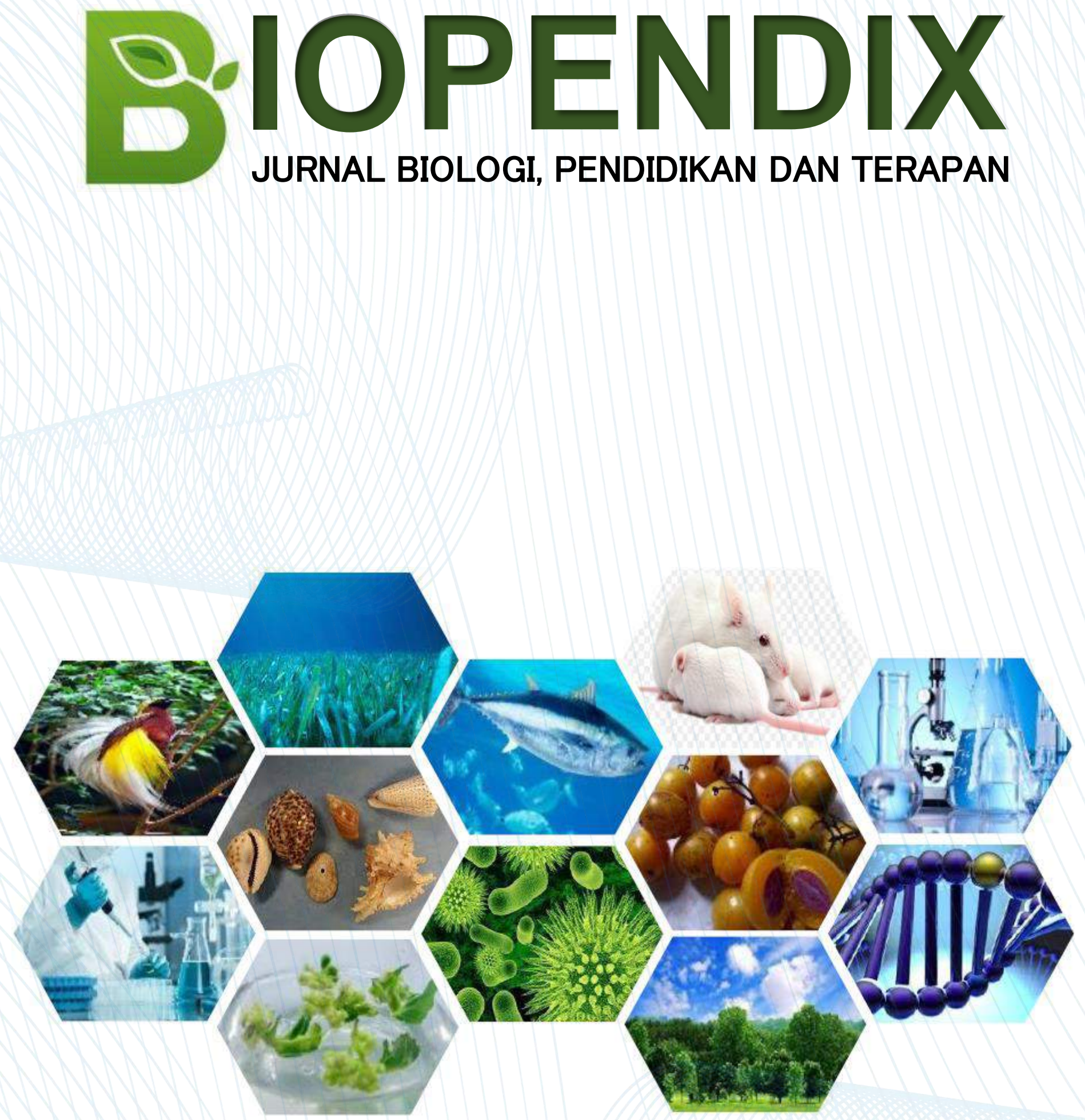

PUBLISHER BY:

BIOLOGY EDUCATION, UNPATTI AMBON - MALUKU 


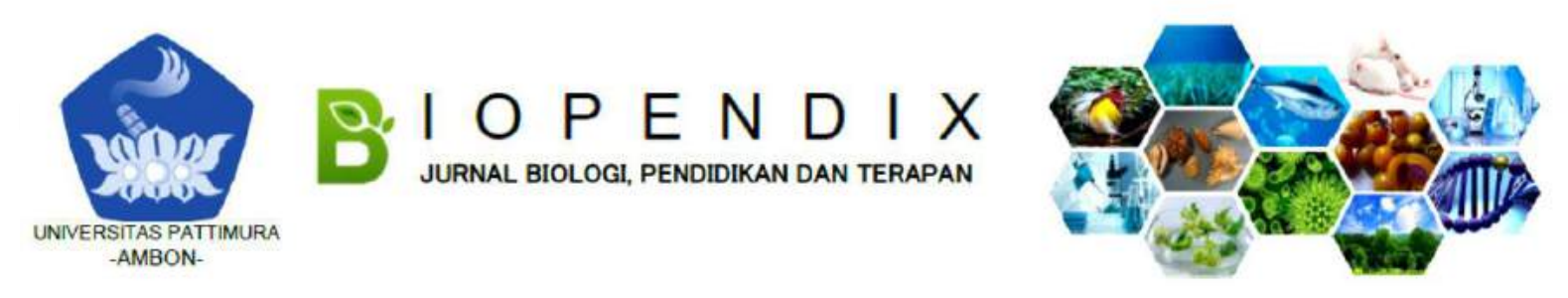

\title{
PENAMBAHAN EKSTRAK DAUN KEMANGI DAN LAMA PERENDAMAN TERHADAP MUTU DAN DAYA AWET IKAN NILA (Oreachromis niloticus) SEGAR
}

\author{
Enjel Souhoka ${ }^{1}$, Alwi Smith², Ine Arini ${ }^{\star 2}$ \\ ${ }^{1}$ Alumni Program Studi Pendidikan Biologi; ${ }^{2}$ Program Studi Pendidikan Biologi \\ *Corresponding author: Ine Arini; e-mail: iairini.unpatti@gmail.com
}

\begin{abstract}
Background: Nila is a tropical fish that likes shallow water. Nila has better nutritional content compared to other freshwater fish, but Nila is also a food that is quickly damaged and spoiled. Pharmacological testing shows that basil has antibacterial activity. Basil leaves contain saponins, flavonoids and tannins which have many benefits besides being a spice in cooking it is also beneficial for bodily health.

Method: This study immersed Nila in basil leaf extract $(30 \mathrm{ml}, 60 \mathrm{ml}, 90 \mathrm{ml})$ dissolved in water to a volume of 0.5 liters for 30 minutes. After that it is stored at room temperature for 0 hours, 4 hours and 6 hours.

Results: The results of the study using the ANOVA test showed that with the addition of basil leaf extract T1 $(30 \mathrm{ml})$, T2 $(60 \mathrm{ml})$ and T3 $(90 \mathrm{ml})$ there was no change in texture, color, odor and eyes on the 4 hour immersion while in the 6 hour immersion there was a change in texture and color.

Conclusion: Based on the results and discussion above, it can be concluded that the addition of basil leaf extract to the freshness of Nila can be seen in 4 hours of immersion because, the results obtained are good, there is no change in the texture, color, odor and eye categories based on 4 sensory test scales. This happens because there is no enzyme, microorganism and chemical activity so that the freshness of the fish is maintained.
\end{abstract}

Keywords: Basil basil, Durability, Tilapia

\section{Abstrak}

Latar Belakang: Nila merupakan ikan tropis yang menyukai perairan yang dangkal. Ikan nila memiliki kandungan gizi lebih baik dibandingkan dengan ikan air tawar lainnya, namun ikan nila juga adalah bahan pangan yang cepat mengalami kerusakan dan pembusukan. Pengujian farmakologi menunjukkan bahwa kemangi memiliki aktivitas antibakteri. Daun kemangi mengandung saponin, flavonoid dan tanin yang memiliki banyak manfaat selain sebagai bumbu masakan juga bermanfaat untuk kesehatan tubuh.

Metode: Penelitian ini melakukan perendaman ikan nila pada ekstrak daun kemangi $(30 \mathrm{ml}, 60 \mathrm{ml}, 90$ $\mathrm{ml}$ ) yang dilarutkan dengan air hingga volume 0,5 liter selama 30 menit. Setelah itu disimpan dalam suhu ruang selama 0 jam, 4 jam dan 6 jam.

Hasil: Hasil penelitian menggunaka uji ANOVA menunjukkan dengan penambahan ekstrak daun kemangi $T_{1}(30 \mathrm{ml}), T_{2}(60 \mathrm{ml})$ dan $T_{3}(90 \mathrm{ml})$ tidak adanya perubahan tekstur, warna, bau dan mata pada perendaman 4 jam sedangkan pada perendaman 6 jam terjadi perubahan pada tekstur dan warna.

Kesimpulan: Berdasarkan hasil dan pembahasan diatas maka dapat disimpulkan bahwa penambahan ekstrak daun kemangi terhadap kesegaran ikan Nila dapat dilihat pada 4 jam perendaman karena, hasil yang diperoleh baik, tidak terdapat perubahan pada kategori tekstur, warna, bau dan mata berdasarkan 4 skala uji sensoris. Hal tersebut terjadi karena tidak adanya aktifitas enzim, mikroorganisme dan kimiawi sehingga kesegaran ikan tetap terjaga.

Kata Kunci: Daun kemangi, Daya Awet, Ikan Nila 


\section{PENDAHULUAN}

Ikan nila merupakan salah satu jenis ikan budidaya air tawar yang mempunyai prospek cukup baik untuk dikembangkan. Ikan nila banyak digemari oleh masyarakat karena dagingnya cukup tebal dan rasanya gurih, kandungan proteinnya tinggi sehingga dapat dijadikan sebagai sumber protein. Menurut Boyd (2004), ikan nila merupakan ikan air tawar yang termasuk dalam famili Cichlidae dan merupakan ikan asal Afrika. FAO (2006), menyatakan bahwa ikan nila merupakan ikan tropis yang menyukai perairan yang dangkal. Ikan nila dikenal sebagai ikan yang tahan terhadap perubahan lingkungan tempat hidupnya. Ikan nila hidup di lingkungan air tawar, air payau, dan air asin. Sumber nutrisi utama ikan nila diperoleh dengan cara memakan makanan pada lapisan perifiton. Ikan Nila tergolong ikan pemakan segala (omnivore), sehingga bisa mengkonsumsi makanan, berupa hewan dan tumbuhan. Larva ikan nila makanannya adalah zooplankton seperti Rotifera sp, Daphnia sp, serta alga atau lumut yang menempel pada bendabenda di habitat hidupnya.

Leksono dan Syahrul (2001), menyatakan bahwa kandungan protein ikan nila sebesar $43,76 \%$; lemak $7,01 \%$, kadar abu $6,80 \%$ per 100 gram berat ikan, sedangkan ikan lele memiliki kandungan protein 40,28\%; lemak 11,28\%; dan kadar abu 5,52. Ikan nila merupakan bahan pangan yang cepat mengalami kerusakan dan pembusukan (persihable food). Ikan nila mulai mengalami penurunan kualitas fisik setelah 2 jam kematian, kerusakan ini dapat terjadi secara biokimia maupun mikrobiologi, hal ini disebabkan oleh beberapa hal seperti kondisi lingkungan yang sangat sesuai untuk pertumbuhan mikroba pembusuk yang diakibatkan bakteri, khamir, maupun jamur. Untuk memperpanjang daya simpan ikan nila lebih awet, selain kadar air yang harus diturunkan maka perlu adanya suatu pengawetan pada ikan nila. Menurut Moeljanto (2002), pada dasarnya pengolahan dan pengawetan ikan adalah mempertahankan nilai kesegaran dari ikan dan mutu ikan sebaik mungkin. Pengolahan dan pengawetan ikan bertujuan untuk menghambat dan menghentikan kegiatan zat-zat dan mikroorganisme yang dapat meningkatkan pembusukan dan kerusakan.

Ada beberapa bahan pengawet yang dapat membahayakan bagi konsumen atau pemakaiannya misalnya, borak, formalin, dan lain sebagainya sehingga dicari alternatif lain yang mampu menghambat pertumbuhan mikroba, memperpanjang masa simpan ikan dengan bahan yang sederhana, mudah didapat dan tidak mengganggu kesehatan yaitu, dengan menggunakan bahan pengawet alami salah satunya adalah ekstrak kemangi (Ocimum bacilicum). Andayani dkk (2014), melaporkan hasil pengujian farmakologi didapatkan bahwa kemangi memiliki aktivitas antibakteri terhadap Saphylococcus aureus, Salmonella enteritidis, Escherichia coli, aktivitas antiseptik terhadap Proteus vulgaris, Bacillus subtilis, Salmonella paratyph, aktivitas antifungi terhadap Candida albicans, Penicillum notatum, Microsporeum gyseum, aktivitas larvasida terhadap lalat rumah dan nyamuk.

Kemangi adalah terna kecil yang daunnya biasa dimakan sebagai lalapan. Aroma daunnya khas, kuat namun lembut dengan sentuhan aroma limau. Daun kemangi merupakan salah satu bumbu bagi pepes. Sebagai lalapan, daun kemangi biasanya dimakan bersama-sama daun kubis, irisan ketimun, dan sambal untuk menemani ayam atau ikan goring. Menurut Tjitrosoepomo (2004), tanaman kemangi yang termasuk dalam famili labyatae berupa terna, jarang berupa tumbuhan kayu, dengan batang yang jelas berbentuk segi empat (pada penampang melintangnya). Daun tunggal, biasanya mempunyai kelenjar-kelenjar minyak astiri. Tanaman kemangi memiliki banyak manfaat yaitu dapat digunakan sebagai bumbu masakan karena aroma yang dihasilkan dari daun menurut Batari (2007), daun kemangi mengandung saponin, flavonoid dan tanin. Sedangkan bijinya mengandung saponin, flavonoid, dan polifenol.

Sulianti (2008), menyatakan bahwa tanaman kemangi memiliki banyak manfaat yaitu dapat digunakan sebagai bumbu masakan karena aroma yang dihasilkan dari daun. Selain itu menurut Rosadi (2007), daun kemangi juga bermanfaat untuk kesehatan tubuh. Lalapan kemangi 
segar dapat mengatasi masalah bau badan, bau mulut, dan ASI kurang subur. Muralidharan \& Dhananjayan (2009), menyatakan tanaman kemangi juga dapat sebagai antipiretik, antiemetik, diuretik, dan kardiotonik. Komposisi gizi daun kemangi per 100 gram bahan mengandung air 87 gram, protein 3.3 gram, serat sebanyak 2 gram, unsur Ca $320 \mathrm{mg}$, unsur Fe 4,5 mg, dan vitamin $C$ sebesar $27 \mathrm{mg}$.

Berdasarkan hal tersebut di atas maka penelitian penting dilakukan untuk mengkaji tentang: penambahan ekstrak daun kemangi dan lama perendaman terhadap mutu dan daya awet ikan nila (oreachromis niloticus) segar.

\section{METODE}

Penelitian ini merupakan penelitian eksperimen guna melihat pengaruh penambahan ekstrak daun kemangi dan lama perendaman terhadap daya awet ikan nila (Oreochromis niloticus) segar. Sampel ikan nila $(5-7 \mathrm{~cm})$ diperoleh dari SUPM Negeri Waiheru Ambon dan pengawetan sampel ikan nila dilakukan di Laboratorium Pendidikan Biologi Fakultas Keguruan dan IImu Pendidikan Universitas Pattimura Ambon. Penelitian ini dilaksanakan mulai dari tanggal 27 Maret 2019 sampai dengan 10 April 2019. Subjek dalam penelitian ini adalah ikan nila segar sebanyak 21 ekor yang diambil secara purposive sampling.

Variabel yang digunakan dalam penelitian ini adalah pengaruh penambahan ekstrak daun kemangi sebanyak $30 \mathrm{ml}$, $60 \mathrm{ml}, 90 \mathrm{ml}$ dan lama perendaman 0 jam, 4 jam, 6 jam. Data yang diperoleh dari penelitian ini akan dianalisis secara deskriptif dengan menggunakan pembanding atau acuan penilaian ikan segar dengan skor nomerik berdasarkan tektur, warna, bau, mata dan insan dimana masing-masing organ ikan atau bagian ikan akan diberikan skor 5 (sangat baik) 3, (baik), 2 (cukup), dan 0 (sangat kurang).

\section{HASIL DAN PEMBAHASAN}

\section{Perendaman Selama 4 Jam}

Dari hasil penelitian dengan menggunakan ekstrak daun kemangi sebanyak $30 \mathrm{ml}, 60 \mathrm{ml}$ dan $90 \mathrm{ml}$, dengan waktu perendaman selama 4 jam pada ikan nila melalui analisis uji sensoris didapatkan hasil bahwa, perlakuan untuk ekstrak daun kemangi $30 \mathrm{ml}, 60 \mathrm{ml}, 90 \mathrm{ml}$, dengan lama perendaman 4 jam untuk kategori tekstur, warna, bau dan mata tidak terjadi perubahan karena tidak adanya aktivitas enzim, mikroorganisme dan kimiawi. Sedangkan terjadi perubahan pada kategori insang yang menurun disebabkan karena air mempunyai hubungan erat dengan mutu suatu bahan pangan, karena semakin tinggi kadar air maka mutu ikan akan cepat mengalami penurunan. Hasil dari proses perlakuan ini dapat dilihat pada Tabel 1.

Tabel 1. Skor Nilai Pengamatan Ikan Nila Setelah di Rendam dengan Ekstrak Daun Kemangi Selama 4 Jam.

\begin{tabular}{|c|c|c|c|c|c|c|}
\hline \multirow[b]{2}{*}{ Perlakuan } & \multicolumn{6}{|c|}{ Penilaian } \\
\hline & Tekstur & Warna & Bau & Mata & Insang & $\begin{array}{l}\text { Daya } \\
\text { Awet }\end{array}$ \\
\hline $\begin{array}{l}\text { Ekstrak daun kemangi } \\
\text { 30ml (a1b1) }\end{array}$ & 5 & 5 & 5 & 5 & 3 & 4 jam \\
\hline $\begin{array}{l}\text { Ekstrak daun kemangi } 60 \\
\mathrm{ml}(\mathrm{a} 2 \mathrm{~b} 1)\end{array}$ & 5 & 5 & 5 & 5 & 3 & 4 jam \\
\hline $\begin{array}{l}\text { Ekstrak daun kemangi } \\
\text { 90ml (a3b1) }\end{array}$ & 5 & 5 & 5 & 5 & 3 & 4 jam \\
\hline
\end{tabular}

Berdasarkan hasil penelitian yang diperoleh menunjukkan bahwa perendaman 4 jam dengan penambahan ekstrak daun kemangi $\mathrm{T}_{1}$ (ekstrak kemangi $30 \mathrm{ml}$ ) $\mathrm{T}_{2}$ (ekstrak kemangi $60 \mathrm{ml}$ ) $\mathrm{T}_{3}$ (ekstrak kemangi $90 \mathrm{ml}) \quad \mathrm{T}_{0}$ (kontrol), tidak menunjukan perubahan pada kategori : tekstur, warna, bau dan mata. Dengan skala uji sensoris kategori 4 di atas disebabkan karena tidak terjadi aktifitas 
enzim, mikroorganisme, dan kimiawi. Sehingga menyebabkan kesegaran ikan tetap bertahan dan tidak mengalami pembusukan. Tetapi terjadi perubahan pada kategori insang yang disebabkan karena kadar air mempunyai hubungan yang erat dengan mutu suatu bahan pangan, karena semakin tinggi kadar air maka mutu ikan akan cepat mengalami penurunan, hal ini disebabkan karena air merupakan media yang cocok untuk pertumbuhan bakteri. Jika dilihat dari waktu perendamannya semakin singkat waktu perendaman maka kadar air semakin rendah, dan semakin lama perendaman maka semakin banyak jumlah kadar air, disebabkan karena terdapat aktifitas metabolisme dan mikroorganisme. Adawyah (2007), menyatakan bahwa daun kemangi memiliki sifat sebagai anti bakteri dan mengandung minyak angin.

\section{Perendaman Selama 6 Jam}

Analisis sensoris untuk perlakuan 6 jam dengan perendaman ekstrak daun kemangi pada ikan nila. Untuk perlakuan ini hasilnya dapat dilihat pada Tabel 2.

\section{Tabel 2. Skor Nilai Pengamatan Ikan Nila Setelah di Rendam dengan Ekstrak Daun Kemangi Selama 6 Jam.}

\begin{tabular}{|c|c|c|c|c|c|c|c|}
\hline \multirow{2}{*}{\multicolumn{2}{|c|}{ Perlakuan }} & \multicolumn{6}{|c|}{ Penilaian } \\
\hline & & \multirow{2}{*}{$\begin{array}{c}\text { Tekstur } \\
3\end{array}$} & \multirow{2}{*}{$\begin{array}{c}\text { Warna } \\
3\end{array}$} & \multirow{2}{*}{$\begin{array}{c}\text { Bau } \\
5\end{array}$} & \multirow{2}{*}{$\frac{\text { Mata }}{5}$} & \multirow{2}{*}{$\begin{array}{c}\text { Insang } \\
5\end{array}$} & \multirow{2}{*}{$\begin{array}{l}\text { Daya } \\
\text { Awet } \\
6 \text { jam }\end{array}$} \\
\hline $\begin{array}{l}\text { Ekstrak daun } \\
\text { 30ml (a1b2) }\end{array}$ & kemangi & & & & & & \\
\hline $\begin{array}{l}\text { Ekstrak daun } \\
60 \mathrm{ml}(\mathrm{a} 2 \mathrm{~b} 2)\end{array}$ & kemangi & 3 & 3 & 5 & 5 & 5 & 6 jam \\
\hline $\begin{array}{l}\text { Ekstrak daun } \\
\text { 90ml (a3b2) }\end{array}$ & kemangi & 3 & 3 & 5 & 5 & 5 & 6 jam \\
\hline
\end{tabular}

Dari hasil penelitian menunjukkan bahwa perendaman 6 jam dengan penambahan ekstrak daun kemangi $\mathrm{T}_{1}$ (ekstrak kemangi $30 \mathrm{ml}$ ) $\mathrm{T}_{2}$ (ekstrak kemangi $60 \mathrm{ml}$ ) $\mathrm{T}_{3}$ (ekstrak kemangi $90 \mathrm{ml}$ ) $\mathrm{T}_{0}$ (kontrol), menunjukkan perubahan pada kategori: tekstur dan warna. Hal ini disebabkan karena, terdapat perubahan pada ikan setelah mati karena adanya aktifitas enzim, mikroorganisme dan kimiawi sehingga menyebabkan kesegaran ikan menurun dan adanya perubahan fisik yang mengarah pada pembunuhan. Tetapi jika dilihat pada perubahan postrigor, pada tahapan ini daging ikan kembali melunak secara perlahan-lahan sehingga semakin lama penyimpanan maka organoleptik tekstur menurun. Sedangkan jika dilihat pada perubahan rigormortis, terjadi karena akibat dari suatu rangkaian perubahan kimia yang kompleks di dalam otot ikan sesudah mati.

Setelah ikan mati, sirkulasi udara berhenti dan suplai oksigen berkurang sehingga terjadi perubahan glikogen menjadi asam laktat. Perubahan ini menyebabkan $\mathrm{pH}$ tubuh ikan menurun, di ikuti dengan penurunan jumlah Adenosin Trifosfat (ATP) serta ketidak mampuan jaringan otot mempertahankan kekenyalannya. Tetapi terjadi perubahan pada rupa ikan seperti warna yang kurang cemerlang bukan hanya disebabkan pengaruh dari pemberian ekstrak daun kemangi tetapi juga dipengaruhi oleh proses biokimiawi lebih lanjut yang menghasilkan lendir pada permukaan kulit ikan.

Adawyah (2007), menyatakan bahwa, berdasarkan analisis fenomena menunjukan bahwa $1 \mathrm{NS}$ dengan $\mathrm{Ne}+\mathrm{DK}$ nutrisi pengaruh nyata terhadap nilai rupa, hal ini disebabkan karena semakin banyak daun kemangi yang di tambahkan untuk analisis rupa semakin cemerlang. Tetapi jika dilihat pada kategori bau, mata dan insang tidak mengalami perubahan disebabkan karena tidak adanya aktifitas enzim, mikroorganisme dan biokimiawi. Sehingga tidak terdapat perubahan pada kategori ini. Hal ini disebabkan karena adanya aroma yang terdapat pada daun kemangi yang menghambat aktifitas bakteri yang akan menimbulkan bau busuk. 
Setyo (2006), menyatakan bahwa secara fisiologi daun kemangi (Ocimum bacilium) merupakan tanaman yang mudah dijumpai dihalaman rumah, masyarakat umumnya mengetahui bahwa daun kemangi hanya digunakan untuk lalapan saja atau sebagai obat tradisional.

Daun kemangi mengandung betakaroten (Provitamin A) dan vitamin C. Daun kemangi mengandung minyak astiri, saponin, flavonoid dan tannin yang dapat menghambat aktivitas bakteri, menambahkan ekstrak daun kemangi juga dapat menghambat aktifitas beberapa bakteri pathogen dan pangan.

\section{SIMPULAN}

Berdasarkan hasil dan pembahasan di atas maka dapat disimpulkan bahwa penambahan ekstrak daun kemangi terhadap kesegaran ikan Nila dapat dilihat pada 4 jam perendaman karena, hasil yang diperoleh baik, tidak terdapat perubahan pada kategori tekstur, warna, bau dan mata berdasarkan 4 skala uji sensoris. Hal tersebut terjadi karena tidak adanya aktifitas enzim, mikroorganisme dan kimiawi sehingga kesegaran ikan tetap terjaga.

\section{DAFTAR PUSTAKA}

Andayani, Triana, Yusuf \& Rini. 2014. "Minyak Atsiri Daun Sirih Merah sebagai Pengawet Alamai pada Ikan Teri. Jurusan Keteknikan Pertanian. Fakultas Teknologi Pertanian. Universitas Brawijaya. Malang. Jurnal.

Adawyah. 2007, Pengawetan dan Pengolahan Ikan. Yogyakarta : Kanisius.

Batari. 2007. "Penggunaan Ekstrak Daun Kemangi Untuk Peningkatan. Daya Simpan Fillet Nila Merah yang disimpan pada Suhu Dingin. Jurnal. Yogyakarta: Jurusan Perikanan, Fakultas Perikanan, Universitas Gadjah Mada.

Boyd. 2004. SNI 01-6139-1999 (Produksi induk ikan nila hitam, Oreochromis nilocitus). Jakarta.

FAO. 2006. Code of Conduct for Responsible Fisheries. Food and Agricultural Organization of The United Nations. Rome.
Leksono, T dan Syahrul. 2001. "Studi Mutu dan Penerimaan Konsumen Terhadap Abon Ikan". http://www.unri.ac.id.

Moeljanto, R. 2002. Pengawetan dan Pengolahan Hasil Perikanan. PT. Penebar Swadaya. Jakarta. $259 \mathrm{hlm}$.

Muralidharan dan Dhananjayan. 2009. Uji Aktivitas Antibakteri Minyak Atsiri Daun Kemangi (Ocimum basilicum L.) Terhadap Staphylococcus Aureus dan Escherichia coli, Jurnal Penelitian Sains \& Teknologi, 8.

Rosadi, A. (2007). Pembuatan Permen Tablet Ekstrak Daun Kemangi (Ocimum Basilicum). Skripsi.bogor.Departemen Ilmu dan Teknologi Pangan, Fakultas Terknologi Pertanian, Institut Pertanian Bogor.

Setyo, S. 2006. Fisiologi Nila (Oreochromis Niloticus), Kanisius. Jakarta. $64 \mathrm{Hal}$.

Sulianti, S.B. 2008. Studi Fitokimia Ocimum spp.: Komponen Kimia Minyak Astiri Kemangi dan Ruku-Ruku. Jurnal IImuIlmu. 9 (3): 237.

Tjitrosoepomo G. 2004. Taksonomi Tumbuhan (Spermatophyta). Gadjah Mada University Press. Yogyakarta. p. 477. 